\title{
Provocateurs and Their Rights to Self-Defence
}

\author{
Lisa Hecht ${ }^{1}$ iD
}

Published online: 23 April 2018

(C) The Author(s) 2018

\begin{abstract}
A provocateur does not pose a threat of harm. Hence, a forceful response to provocation is generally considered wrongful. And yet, a provocateur is often denied recourse to a self-defence justification if she defends herself against such a violent response. In recent work, Kimberly Ferzan argues that a provocateur forfeits defensive rights but this forfeiture cannot be explained in the same way as an aggressor's rights forfeiture. Ordinarily, one forfeits the right not to be harmed and to selfdefend against harm by threatening to violate another person's rights. But provocateurs forfeit their defensive rights because they bring about the situation in which defence becomes necessary. As I argue here, positing these two types of forfeiture justifications is neither desirable nor necessary. I suggest a unified rights forfeiture account that grounds rights forfeiture in moral responsibility for an unjust threat. My account offers clearer distinctions than alternative unified accounts, which I briefly discuss. Furthermore, the account can provide better explanations of intuitively plausible judgements. A provocateur will have less extensive defensive rights than an innocent victim, but will not lose all her defensive rights simply because 'she started it.'
\end{abstract}

Keywords Provocation $\cdot$ Rights forfeiture $\cdot$ Self-defence $\cdot$ Actio libera in causa

\section{Introduction}

A provocateur does not pose a threat of harm. Hence, a forceful response to provocation is generally considered wrongful. And yet, a provocateur is often denied

Lisa Hecht

lisa.hecht@philosophy.su.se

1 Department of Philosophy, Stockholm University, Stockholm, Sweden 
recourse to a self-defence justification if she defends herself against such a violent response. This denial is based on the actio libera in causa principle. According to this legal principle, an agent cannot invoke an excuse or justification for an otherwise wrongful act (here, defence against the respondent) if she brought about the excusing or justifying conditions herself. A provocateur causes another to lose selfcontrol and so creates the need for her own defence. Therefore, she may not invoke a self-defence justification for using force. Many find this principle intuitive since it marks a perceived difference between provocateurs and innocent victims of harm.

In recent work, Kimberly Ferzan offers a defence for the moral underpinnings of the actio libera in causa principle as applied to provocation cases. She argues that, despite not being liable to harm, provocateurs forfeit their right to self-defence. According to Ferzan, a provocateur's rights forfeiture cannot be explained in the same way as rights forfeiture of an aggressor. Ordinarily, one forfeits the right not to be harmed and to self-defend against harm by threatening to violate another person's rights. But "[p]rovocateurs forfeit their defensive rights for the very simple reason that they start the fight."1

As I argue here, positing these two types of forfeiture justifications is neither desirable nor necessary. This separation approach has the odd implication that, in some situations, aggressors are better off than provocateurs in terms of permissible self-defence. Even if this problem could be resolved, Ferzan's account still cannot offer a suitable constraint on rights forfeiture and thus clashes with strong intuitions about the importance of proportionality. Both of these problems flow directly from the separation of forfeiture justifications in provocation and aggression cases.

Taking a unified approach to defensive rights forfeiture in provocation and ordinary aggression cases could avoid the problems that Ferzan's account faces. I suggest a unified rights forfeiture account that grounds rights forfeiture in moral responsibility for an unjust threat. My account offers clearer distinctions than alternative unified accounts, which I briefly discuss. My account has the further advantage of aligning with our intuitions. A provocateur will have less extensive defensive rights than an innocent victim, but will not lose all her defensive rights simply because 'she started it.'

\section{Treating Provocation as a Special Case}

\subsection{Intuitions and the Law}

Ordinarily, people have a right to defend themselves against the infliction of wrongful harm. However, to grant a provocateur who recklessly or intentionally brings about the conditions of her own defence the same extensive defensive rights as any other victim of wrongful harm looks morally suspect. The following case illustrates the issue:

\footnotetext{
${ }^{1}$ Kimberly Kessler Ferzan, "Provocateurs," Criminal Law and Philosophy 7(3) (2013): p. 597.
} 


\section{Provocation}

Provocateur wants to pick a fight in a bar. She starts teasing and offending Respondent so that she will start the fight. Finally, Respondent shows the desired reaction. She gets up to knock Provocateur out. But Provocateur hits her first and breaks her nose. She claims it was self-defence.

In this case, Provocateur teases Respondent causing a violent response that would, prima facie, grant her permission to fight back. Most people would think that Respondent should not strike Provocateur. Still, sympathies for Provocateur are probably limited if Respondent does indeed strike her. If she anticipated, or even intended, Respondent's reaction, and still provoked that reaction, then how can she complain about being harmed? Provocateur is not an innocent victim of Respondent's attack.

Ferzan wants to account for these intuitions, and her account is in line with various jurisdictions and their treatment of provocation cases. Ferzan's treatment of provocation cases can be considered to reflect or be grounded in two moral judgements.

First, the respondent acts wrongly in harming the provocateur. Within jurisprudence, those who defend provocation as a mitigating circumstance argue that provocation creates either a partial excuse or a partial justification. However, such partial excuses and justifications cannot fully exculpate the respondent. ${ }^{2}$ On both views, striking against a provocateur is deemed at least partially wrongful.

Ferzan similarly argues that it is impermissible to harm provocateurs. This distinguishes provocation from most cases of aggression. Aggressors act in a way that leads to their forfeiting rights, rendering them liable to defensive force. By culpably posing — or culpably appearing to pose - a threat, an aggressor forfeits her rights against defensive harm. Harming the aggressor would not wrong her if the victim can thereby avert the threat or-in case of apparent threats-believes she can thereby avert the threat. ${ }^{3}$ Provocateurs do not pose a threat and do not appear to pose a threat. Without an actual or apparent threat, harm to a provocateur cannot be justified as defensive harm. Therefore, it would wrong the provocateur if the respondent were to harm her. ${ }^{4}$

However-and this is the second considered judgement about provocation cases - the provocateur is implicated in the respondent's wrongdoing and should not be treated as an innocent victim. This is reflected in the law of various jurisdictions, which holds that provocateurs may not appeal to self-defence should they use force against a respondent. ${ }^{5}$ Provocateurs are treated under the actio libera in causa

\footnotetext{
${ }^{2}$ For a discussion of the justificatory and exculpating elements in a provocation defence, see Jeremy Horder, Provocation and Responsibility (Oxford: Clarendon Press, 1992), pp. 112-136.

${ }^{3}$ Kimberly Kessler Ferzan, "Culpable Aggression: The Basis for Moral Liability to Defensive Killing," Ohio State Journal of Criminal Law 9(2) (2012): p. 670.

4 Ferzan (2013, p. 607).

5 Ferzan (2013, p. 598).
} 
principle. ${ }^{6}$ This legal principle applies to cases in which the defendant causes the conditions of her own defence. The provocateur would have a justification for selfdefence if it were not for the fact that she brought about the conditions under which self-defence becomes necessary.

Just like the law, Ferzan explains the impermissibility of a provocateur's selfdefence by the fact that a provocateur brings about the situation in which she has to defend herself. As Ferzan puts it, "as any elementary age child will tell you, the playground rule-'he started it'-has moral traction."7 Ferzan accounts for this moral judgement by arguing that the provocateur forfeits defensive rights against foreseen harm and therefore lacks a justification for harming the respondent. Ferzan explains this alteration in the moral status of provocateurs as follows: "a provocateur creates the risk that another person will harm him by engaging in conduct that he knows may produce a violent response." 8 The provocateur forfeits her moral complaint and her right to self-defence "for the very simple reason that provocateurs start the fight" and so in a sense were "asking for it." 9

One implication of Ferzan's account is that there are two different rationales for defensive rights forfeiture. An aggressor forfeits her rights because she poses a threat. A provocateur forfeits her rights because she brings about a situation in which she must defend herself. Rights forfeiture in the case of provocateurs is limited to the forfeiture of defensive rights and possibly the right to claim compensation. ${ }^{10}$ She retains a right against harm. In contrast, aggressors forfeit rights against being harmed as well as the rights to self-defence and compensation.

To avoid the account's becoming too permissive, Ferzan limits it to instances in which the provocateur knowingly and unjustifiably creates the risk of harm to herself. ${ }^{11}$ As Ferzan admits, the question of justifiability is difficult to settle. But without this constraint the very general formulation of "creation of a risk that another would harm him" would make defensive rights forfeiture an implausibly common occurrence. ${ }^{12}$ Even though the question of justifiability is of central importance to provocation cases, I will not address it here. I assume that there are instances of unjustified provocation and that only unjustified provocation affects the provocateur's rights.

With this account, Ferzan captures the strong intuitions that explain the denial of a self-defence justification in provocation cases. In the following sections, I identify some problematic implications of her account.

\footnotetext{
6 Ferzan (2013, p. 598).

7 Ferzan (2013, p. 615).

8 Ferzan (2013, p. 615).

9 Ferzan (2013, p. 615).

10 Ferzan suggests this much in Ferzan (2012, p. 693).

11 Ferzan (2013, pp. 615-616).

12 Ferzan (2013, p. 618).
} 


\subsection{Proportionality and the Foreseen Harm Constraint}

Since Ferzan invokes two different rationales for defensive rights forfeiture, we also find two different constraints on the extent of forfeiture. Whereas an aggressor forfeits defensive rights proportionate to the harm she poses, a provocateur's rights forfeiture is limited by a foreseen harm constraint.

In ordinary self-defence cases, proportionality is a constraint on the permissible use of force and the forfeiture of defensive rights. The aggressor forfeits her rights against harm in proportion to the threat she poses and the victim is justified in harming defensively because of the valuable goal-the aversion of wrongful harm-that this would secure. Thus, there are generally two aspects to proportionality considerations. The permissibility of harming the aggressor is determined by the valuable goal. But the extent to which an aggressor forfeits defensive rights and becomes liable to harm is limited by the threat she poses.

In addition to the weighing of harms, many views also take moral responsibility as a variable that affects proportionality. ${ }^{13}$ That is, an aggressor's diminished moral responsibility, for example, because of duress or lack of control, will reduce what counts as proportionate defence.

Ferzan cannot appeal to such a proportionality constraint. She uncouples a provocateur's forfeiture of defensive rights from posing a wrongful threat. One consequence of this uncoupling is that there is no wrongful threat that can be used as yardstick for determining proportionality. Ferzan therefore suggests an alternative constraint on defensive rights forfeiture. How much of her defensive rights the provocateur forfeits will be capped by the amount of force that she foresaw she would provoke. She explains:

This means that it is only when a provocateur is subjectively aware that he is potentially causing another to attack him that the provocateur forfeits his defensive rights. And to be clear, the provocateur should only forfeit employing the degree of force that he subjectively appreciates. If he only foresees non-deadly force, then he only forfeits his right to use non-deadly force. ${ }^{14}$

Thus, if a provocateur foresees a violent reaction and anticipates receiving a punch, she forfeits her defensive rights against being punched but not against being met with lethal force. However, if she anticipates a lethal response to her provocation, she may not self-defend against such harm even though it is wrongful.

Such a constraint on defensive rights forfeiture can be more permissive than a proportionality constraint. On Ferzan's account, the provocateur could be required to suffer very severe harm if this is what she foresaw as a reaction. For example, knowing that someone might well use lethal force to defend his mother's honour means that a provocateur who insults the mother may not resist a lethal response from the

\footnotetext{
${ }^{13}$ For an overview of these views, see Jonathan Quong, "Proportionality, Liability and Defensive Harm," Philosophy \& Public Affairs 43(2) (2015): pp. 145, 152. Quong himself does not endorse such a view.

14 Ferzan 2013, p. 616.
} 
son. This looks out of proportion to the provocation. And if we judge proportionality to be ordinarily an important constraint on the extent to which a wrongdoer forfeits rights, it is implausible that it is discarded in the case of provocateurs.

One might not share this intuition. Within tort law, the assumption of risk-similar to consent - bars recovery should the risk materialize in harm. ${ }^{15}$ For example, if someone goes on a rollercoaster ride and consents to the risk of suffering a harm as part of the activity, she may not sue or claim recovery if she ends up suffering that harm. In this context, the notion of forfeiting enforcement rights is not considered problematic. The agent simply has to bear the costs once risk materializes into harm. The legal analysis suggests that a risk-taker can be made to bear the full costs she incurs after voluntary assumption of risk. So why worry about the proportionality of the cost a provocateur incurs if this is similarly the result of her assumption of a risk to be harmed? ${ }^{16}$

Especially in the context of distributive justice, scholars push back against the idea that one can be made to bear any cost provided that this cost was the result of a voluntary assumption of a risk. Most prominently, Elizabeth Anderson argues that there is something morally troubling about any theory that lets the full costs of risks fall on those who voluntarily assume those risks. Leaving a motorcyclist to die because he knowingly took a risk when driving without a helmet, and ends up suffering serious harm, seems too harsh a consequence of an imprudent choice. ${ }^{17}$ Although the outcome can be attributed to the voluntary assumption of a risk, he should not bear just any cost that he risked incurring. Note, too, that pointing to the prospective cost of rescue does not rebut this reply. It may be that one ought to be prepared to bear more cost for the sake of a motorcyclist who took a smaller risk-for example, that a rescuer should bear more cost to save the rider with a helmet than the one without. But when one can save without bearing any significant cost, it is hard to believe that one may leave a more reckless rider to die because he brought it on himself-rather, the assumption of risk seems irrelevant in any kind of easy rescue case. Similarly, in provocation cases, the respondent has an opportunity to refrain from harming without bearing any significant cost herself. Given this, the easy rescue standard seems the appropriate comparison, irrespective of what we think of the role of risk assumption in comparative cases. ${ }^{18}$

Meeting the harshness objection demands some notion of proportionality: while agents should be held responsible for their choices, the costs they incur as a consequence should not be excessive in comparison to their choices. ${ }^{19}$ By way of elaboration on the notion of excessiveness, Robert Goodin suggests that we hold agents responsible for an outcome only to the degree to which the outcome was likely to

\footnotetext{
${ }^{15}$ Kenneth W. Simons, "Assumption of Risk and Consent in the Law of Torts: A Theory of Full Preference," Boston University Law Review 67(2) (1987): p. 214.

${ }^{16}$ Thanks to a reviewer for the example and objection.

${ }^{17}$ Elizabeth S. Anderson, "What is the Point of Equality?," Ethics 109(2) (1999): pp. 295-296.

18 Thanks to Helen Frowe for the objection and the reply to the objection.

${ }^{19}$ For discussion of the harshness objection and various ways to avoid it while still holding agents responsible for their choices, see: Kristin Vogt, "The Harshness Objection: Is Luck Egalitarianism Too Harsh on the Victims of Option Luck?," Ethical Theory and Moral Practice 10 (2007): pp. 389-407.
} 
occur. $^{20}$ Alternatively, Peter Vallentyne suggests that we hold agents responsible only for that part of the outcome that can be attributed to their choices rather than brute luck. $^{21}$

We find, then, that there is a genuine concern in moral theory about the costs an agent should be made to bear upon the assumption of a risk. Even though an agent might voluntarily assume a risk and foresee the potential consequences of this choice, this does not yet render any cost that befalls her morally unproblematic. We still have reason to be concerned with the proportionality of the cost an agent is required to bear. Considerations about proportionality should not merely come in when determining the extent to which one can become liable to harm but should also matter when determining the costs people have to bear for risks they assumed. Forfeiting defensive rights up to the amount of foreseen harm might therefore turn out to be an overly harsh or disproportionate cost of the provocateur's actions.

A further problem with the foreseen harm constraint is that the extent of a provocateur's rights forfeiture varies with her prediction of the respondent's reaction. If, on the one hand, I foresee that some minor insult will lead to a lethal response, I will lose all defensive rights. If, on the other hand, I expect my hurtful and deeply offensive provocation will incite nothing more than a hard shove, I will retain extensive rights. Assume that my prediction is wrong in the second case, and the respondent reacts with lethal force. I may still defend against the harm that exceeds what I anticipated, even though my provocation was much worse than in the first case. This looks like an unfair implication of the foreseen harm constraint.

Thus, Ferzan's account comes into conflict with the importance usually attributed to proportionality. It also makes defensive rights and permissible defensive action heavily dependent on the provocateur's predictions.

\subsection{A Peculiar Asymmetry}

Provocation is often a lesser wrong than physical aggression. However, on some occasions, Ferzan's account could make provocateurs worse off than aggressors in terms of self-defence, which seems mistaken.

To see how the account does not make the relevant distinctions, consider the protective function of rights. Rights protect important interests. ${ }^{22}$ One can think of rights as consisting of several layers of protection for a particular interest. At any given time, we are each under a duty not to violate other people's rights. If someone disregards this duty, people have the right to defend themselves (and others) against violations of their rights. Should the victim be unsuccessful in defending her rights, she may later claim redress.

Initially, an aggressor's interests in not being harmed are less well protected than a provocateur's - and rightly so. An aggressor forfeits her rights against harm and

\footnotetext{
${ }^{20}$ Robert Goodin, "Negating Positive Desert Claims,” Political Theory 13(4) (1985): pp. 583-585.

21 Peter Vallentyne, "Brute Luck and responsibility," Politics, Philosophy \& Economics 7(1) (2008): pp. 57-80.

22 See, for example, Joseph Raz, The Morality of Freedom (Oxford: Oxford University Press, 1986).
} 
subsequently the right to self-defend and to claim compensation, whereas a provocateur only forfeits her defensive rights (and possibly rights to compensation) but retains her right against harm. At first a provocateur is equally well protected as an innocent victim: both have a right against harm and would be wronged by the infliction of such harm. Fortunes change, however, if the respondent or a third party disrespect the commands of morality and threatens the provocateur. Then the provocateur might end up worse than an aggressor. Should her target decide to strike back, the aggressor has forfeited rights only in proportion to the harm she was threatening. The provocateur, in contrast, forfeits rights up to the amount of harm she foresaw. The asymmetry becomes clear in the comparison of the following two cases of self-defence.

\section{Aggression}

Aggressor tries to punch Victim. Victim reacts in time and moves to defend herself with lethal force against the punch.

\section{Provocation II}

Provocateur wants to pick a fight and expects that her insulting words will incite Respondent to try to use lethal force.

On most accounts of self-defence, Aggressor would not be liable to suffer defensive harm that greatly exceeds the harm she was threatening. Lethal defensive force is disproportionate to the threat of a punch and so Aggressor retains her right to selfdefend against the disproportionate harm.

Not so in the case of the provocateur-if Ferzan is right. If Provocateur foresees Respondent's reaction and nevertheless provokes her, she then forfeits her defensive rights against whatever harm she predicts Respondent will inflict. Provocateur is not liable to suffer this harm and Respondent acts wrongly in harming her. Still, once Respondent disregards the commands of morality, Provocateur cannot permissibly defend her interest.

In this respect, a provocateur is in a worse position than an aggressor in terms of rights protection. The provocateur must rely on other's respect for moral commands, whereas an aggressor can actively enforce compliance. This seems to be getting things the wrong way around. After all, the aggressor does more wrong than the provocateur. It is an odd implication of Ferzan's account that the aggressor should be in a better position with respect to defensive rights than the provocateur despite acting more wrongly.

Ferzan could avoid this peculiar asymmetry by applying the same constraint on defensive rights forfeiture to provocateurs and aggressors. While the permissibility of harming both aggressors and provocateurs might still be subject to a proportionality constraint, both forfeit defensive rights against harm that they foresee. Making this modification seems only natural, since Ferzan's rationale for defensive rights forfeiture would apply equally well to aggressors. Just like the provocateur, the aggressor starts the fight and thereby risks harm to herself. In that respect, all aggressors look like reckless provocateurs. Ferzan could plausibly extend her argument to 
aggressors. It is foresight - along with the unjustified, deliberate or reckless creation of risk of harm to oneself-that explains forfeiture in both types of case.

This means giving up the proportionality constraint on defensive rights forfeiture, because forfeiture is no longer linked to the degree of the unjustly threatened harm. Such a solution would have far-reaching consequences for defensive rights generally. If one's defensive rights were dependent on the anticipated reaction, this would make the protection of one's interest more dependent on other people's actions. Whether one will be protected against disproportionate harm-and not just against the harm one foresees-will depend on one's opponent. Once the opponent oversteps the limits of proportionality and acts wrongfully, one may still not self-defend if this reaction was anticipated.

This leads back to the worries raised in the previous section. Even wrongdoers should not suffer disproportionate harm. And, in order to protect them from such disproportionate harm, proportionality should not only affect the duties that others must refrain from harming but also give them the right to defend against eventual disregards of those duties.

Overall, the account places provocateurs somewhere between aggressors and innocent victims with regards to the protection of their rights. At first, their rights protect them against harm. But, if someone threatens harm, provocateurs might become worse off than aggressors, for they lose their defensive rights up to the amount of harm they foresee. Ideally, an account should show why provocateurs are not worse off than aggressors when threatened with harm. I will show how my account more easily handles those cases after I present the details of my account in the following section.

\section{A Unified Forfeiture Account}

\subsection{Provocateurs as Indirect Threats}

Ferzan suggests that provocateurs are different from aggressors, which, as we have seen, creates problems for her account. The main difference between provocateurs and aggressors consists in the fact that "aggressors do, but provocateurs do not, engage in behavior that renders them liable to defensive force." ${ }^{23}$ Aggressors are liable to harm because they pose threats that can be averted by harming them. But there is reason to doubt this categorical distinction between provocateurs and aggressors. Ferzan herself admits that some cases fall on the border of the provocateur/aggressor divide and that some actors could be both aggressors and provocateurs. ${ }^{24}$ Provocation and aggression are on a spectrum with no obvious cut-off point that could justify applying one forfeiture principle rather than the other. It might not always be clear whether one is a mere provocateur, or an apparent or actual threat. For example, imagine that, in a heated argument and a scuffle in a bar, one of the parties

\footnotetext{
23 Ferzan (2013, p. 607).

24 Ferzan (2013, p. 609, footnotes 54, 55).
} 
pushes the other repeatedly and issues challenges like "try me, go ahead, punch me before I get you first" without himself making a move to inflict serious harm. In such and similar cases, the borders between provocation and threat are fluid.

The difficulty of sustaining a clear distinction between provocateurs and aggressors gives us further reason to endorse a unified rationale for rights forfeiture that applies equally to provocateurs and aggressors. I suggest that provocateurs are similar to indirect threats and it is this fact that explains their rights forfeiture. As Helen Frowe argues, indirect threats make a contribution to, and so bear moral responsibility for, an unjust threat. She defines an indirect threat as "a person whose movements, actions, or presence contribute, or have contributed, to the threat to Victim [...], but who will not [harm] victim. Contributing to the threat can include helping to bring the threat about [...]." 25 Their contribution leads to forfeiture of rights against harm and can make them liable to defensive harm. The description of indirect threats, and so the implications, applies to provocateurs as well.

Although the provocateur does not pose a wrongful threat, she contributes to the wrongful threat posed by the respondent. Without the provocation, there would be no threat of harm. Therefore, one can assign some responsibility for the threat coming about to the provocateur. The provocateur is still not liable to be harmed. But her contribution leads to forfeiture of part of her defensive rights.

Consider the following case to see the analogy:

\section{Intoxication}

Ben has a violent temper that makes him threaten people when he is drunk. His friend knows this but keeps topping up his drink. As a result, Ben loses his temper and threatens to break innocent Anna's leg because he hates her. Before she can strike in self-defence, his friend calls out, "Careful with him. I filled him up."

Notice how this case is structurally similar to Ferzan's example of Iago and Othello. $^{26}$

\section{Othello}

Iago taunts Othello with false claims that Desdemona is unfaithful. Othello is enraged and threatens to kill Desdemona.

Ferzan presents Othello in order to show how "[p]rovocateurs often have others do the dirty work." 27 The similarities between provocateurs and indirect threats are apparent in cases involving three parties. Iago turns into an indirect threat to Desdemona by provoking Othello. But Ferzan would treat Iago as a provocateur if Othello wrongfully threatens him instead of Desdemona. I suggest that we treat both these cases as instances of indirect threats.

\footnotetext{
${ }^{25}$ Helen Frowe, Defensive Killing (Oxford: Oxford University Press, 2014), pp. 32-34.

${ }^{26}$ Ferzan (2013, p. 598).

${ }^{27}$ Ibid.
} 
Drunken Ben has a partial excuse for the wrongful threat. He is only partly responsible for being drunk and so his moral responsibility is reduced. Othello is morally similar to Ben in Intoxication. They both pose partially excused threats. Their threats are wrongful but they are to some extent excused. Othello and Ben are no longer in full control of themselves and somebody else contributed to their being in this state. The respondent's threat remains equally impermissible but also equally excused if the target is the provocateur himself rather than an innocent third party. In this respect, there is no difference between three party cases and cases involving only the provocateur and the respondent.

According to some accounts, a partial excuse affects the degree of an agent's moral liability to defensive harm and, in turn, the proportionality restriction. ${ }^{28}$ An innocent victim should exercise more restraint in self-defence. Anna and Desdemona are thus required to use less force against the partially excused threat than they would be permitted to use when facing a fully culpable threat. This means that if Anna could avert the threat by either breaking Ben's arm, or by breaking his finger and letting herself be painfully shoved, she should choose the latter option. But, if the aggressor was culpable and had no excuse, it would be proportionate to break the aggressor's arm in self-defence. ${ }^{29}$ It would be odd if a provocateur were in the same moral position as Anna in Intoxication. We expect Anna to exercise more restraint because she is facing a partially excused threat. Can't we require more still of a provocateur who started the fight?

I propose that we think of provocateurs as being in some ways morally akin to the friend in Intoxication. If that is so, it will be instructive to consider how the friend's defensive rights are affected by his contribution to the threat. In Intoxication, the friend enters the scene declaring some responsibility for the drunk's being in that state. If Anna could use the friend as a shield and thereby expose him to some harm, this seems permissible. Because of his contribution to the threat, the friend lost some of his rights against harm and became liable to suffer some harm to avert the threat to which he contributed. Similarly, Iago contributes to the wrongful threat to which Desdemona is exposed. He therefore forfeits some of his rights against harm and becomes liable to harm to protect Desdemona. Provocateurs do not pose a direct threat but they contribute to the partially excused threat now posed by the respondent. Again, this holds in cases in which a third party is threatened and in cases in which the provocateur is threatened. A provocateur's contribution to a wrongful threat explains the rights forfeiture.

The similarities might be slightly less apparent in cases involving only the provocateur and the respondent, like in the initial case Provocation. With regards to the provocateur's culpability, Ferzan suggests herself that culpability does not change once we move from three-person cases like Othello to cases involving only the provocateur and respondent. ${ }^{30}$ I suggest that more generally we can treat those cases

\footnotetext{
28 For example, Jeff McMahan, Killing in War (Oxford: Oxford University Press, 2009), p. 156.

29 Readers can adjust the harms as they think fit: the important point is that one should bear more cost for the sake of an innocent or partially excused aggressor than a culpable aggressor.

30 Ferzan (2013, p. 602).
} 
alike. In both cases, the provocateur contributes to a wrongful threat either to herself or to others. The main difference between those types of cases is that a provocateur cannot be liable to the respondent's harm as she could be liable to defensive harm if her provocation leads to a threat to an innocent party. This is explained by the instrumentality requirement of liability. With respect to defensive harm, one can be liable to that harm only if the harm will be instrumental in the aversion of a threat. ${ }^{31}$ By posing a threat, an aggressor forfeits her rights against defensive harm. But she will be liable to harm only if that harm is instrumental to averting the threat to her victim. This is not so in the case of provocateurs. Provocateurs do not pose a threat and so harm used against them does not serve the purpose of threat aversion. Without a threat, harm to a provocateur cannot be instrumental and she cannot be liable to it. Therefore, harming a provocateur remains wrongful and the respondent is not permitted to inflict harm. ${ }^{32}$

Now, if, as I suggest, Intoxication is deemed sufficiently analogous to provocation cases, we can draw the conclusions that I suggested above. The respondent poses a wrongful but partially excused threat. The provocateur contributes to this threat's coming about and therefore forfeits some of her rights. But because harming her would not be instrumental to the aversion of the threat of harm-rather, harming her is the threat—-she is not liable to be harmed.

\subsection{Partial Responsibility and the Extent of Rights Forfeiture}

An important question that remains to be answered is how we can determine the extent of the provocateur's rights forfeiture. In the following, I argue that a provocateur forfeits rights in proportion to her contribution to the wrongful threat. While it is beyond the scope of this paper to offer a full account and defence of partial responsibility, I sketch what such an account could look like in the case of provocation.

As the previous discussion illustrates, both the provocateur and the respondent bear moral responsibility for an unjust threat. The provocateur's rights forfeiture will depend on the degree to which she contributed to that threat. On most views of defensive harm, proportionality is determined by the extent to which an attacker is morally responsible for a wrongful threat. Moral responsibility requires that the action can be ascribed to an agent (agential responsibility) but also takes into account the intentions and beliefs of the agent. ${ }^{33}$ The most common way in which an outcome is ascribed to an agent is by establishing a causal link between her action and the outcome. Once we establish agential responsibility for the outcome, we can

\footnotetext{
31 This distinguishes the liability account, which I endorse from Ferzan's. Ferzan rejects the necessity requirement in order to explain why apparent threats can be liable to harm (Ferzan 2012, p. 689). I follow liability accounts that make instrumentality a requirement for liability. See, for example, Helen Frowe, pp. 89-90. Others, like Jeff McMahan, argue for a more restricted notion of liability. Defensive harm must not only be instrumental but also necessary to the aversion of a threat (McMahan, p. 8.). However, there is wide agreement that permissible infliction of defensive harm must be at least instrumental to the aversion of a threat.

32 Ferzan (2013, p. 607).

33 Frowe, p. 74.
} 
further consider how different degrees of moral responsibility affect the extent of her rights forfeiture.

It is a matter of ongoing debate whether we can sensibly speak of differently sized causal contributions to an outcome. ${ }^{34}$ Being able to explain how contributions to an outcome come in different sizes would be an advantage of any causal theory, given that this common-sense idea finds wide application within law and morality. Explaining permissible defensive harm, Cécile Fabre, ${ }^{35}$ Jeff McMahan, ${ }^{36}$ and Seth Lazar $^{37}$ all rely on the idea that one can contribute more or less to a threat. Also, the differentiation of accomplice and principal liability, of abettors, inciters and perpetrators, ${ }^{38}$ and the notion of proximate cause within the law presupposes that responsibility can vary not just on grounds of differential culpability, but also the extent of one's contribution to the outcome. These differentiations would of course be misguided if they did not rest on a plausible metaphysics of causation.

Recent probabilistic accounts of causation could be a promising way to capture the idea of differently sized contributions to an outcome. ${ }^{39}$ Rather than committing to any one account in particular, I merely want to point out here that one can offer an explanation of how different agents contribute to different degrees to an outcome. Other accounts might give different explanations but I leave it for further discussion what the most plausible account of partial responsibility would be.

Peter Vallentyne provides some clues as to how one could assess the responsibilities of both the involved parties. Building up on his account of agential responsibility, I suggest that the provocateur bears responsibility for the outcome to the extent that she changes the respondent's disposition to choose one course of action rather than another.

Vallentyne suggests that an agent can be held responsible for an outcome insofar as it reflects autonomous choice rather than brute luck or another person's influence. In each case, one must consider the initial choice disposition of the agent, which determines the likelihood of the outcome occurring. For example, if I am very hungry, my disposition to eat the cake in front of me will be very high, about $90 \%$ (because I am very hungry). My disposition not to eat the cake is only 10\% (because

\footnotetext{
${ }^{34}$ For those who deny partial responsibility for an outcome based on differently sized contributions, see Frowe, p. 44; Sara Bernstein, "Causal Proportions and Moral Responsibility," in David Shoemaker (ed.), Oxford Studies in Agency and Responsibility, Volume 4 (Oxford: Oxford University Press, 2017). For criticisms of Michael Moore's particular approach to assigning partial responsibility on the basis of different causal contributions and its application in law, see Helen Beebee et al., "Legal Responsibility and Scalar Causation," Jurisprudence 4(1) (2013): pp. 102-108; Larry Alexander, and Kimberley Kessler Ferzan, “"Moore or Less' Causation and Responsibility," Criminal Law and Philosophy 6(1) (2012): pp. 81-92.

${ }^{35}$ Cécile Fabre, "Guns, Food, and Liability to Attack in War," Ethics 120(1) (2009): pp. 60-61.

36 Jeff McMahan, Killing in War (Oxford: Oxford University Press, 2009), p. 225.

${ }^{37}$ Seth Lazar, Sparing Civilians (Oxford: Oxford University Press, 2015), pp. 94-95.

38 Joshua Dressler, for example, argues for the differentiation of minor and major accomplices depending on the significance of their causal contribution to the crime. See Joshua Dressler, "Reforming Complicity Law: Trivial Assistance as a Lesser Offense," Ohio State Journal of Criminal Law 5 (2008): pp. 427-448.

${ }^{39}$ For example, Vallentyne (2008); Alex Kaiserman, "Partial Liability," Legal Theory 23(1) (2017): pp. $1-26$.
} 
it is not my cake). If I end up eating the cake, the outcome will only be $10 \%$ attributable to my choice, with the rest attributable to factors beyond my control (ignoring any prior choices I made - assume it was bad brute luck that I ended up hungry). If, however, I refrain from eating the cake, the outcome can be $90 \%$ attributed to my choice.

In cases of threats and offers, Vallentyne suggests, third parties can influence the initial choice disposition of agents. The extent to which this will happen depends on the severity of the threat. He writes, "[a] credible threat that one will be slapped if one does not hand over one's wallet typically has little impact on one's choice disposition and the threatened agent can be responsible for perhaps a significant shift in probabilities if she hands over her wallet." 40 Such a minor threat might increase the initial disposition of an agent to give away her wallet from $0 \%$ to, say, for example, $20 \%$. If, upon the threat, the agent hands over her wallet, she will bear $80 \%$ responsibility for the outcome, while the threatener will be responsible for the shift of $20 \%$ in her disposition. ${ }^{41}$ However, if the threat is very serious, making it almost certain that the agent will give away her wallet (say her disposition to do so increases to $90 \%$ ), then the threatener will bear responsibility for the $90 \%$ shift in the agent's disposition, while the agent's autonomous choice contributed only $10 \%$ to the outcome occurring. The threatener made it more likely that the outcome will occur and bears responsibility for this increase.

We can apply this reasoning to provocation cases. The provocateur is only indirectly responsible for the outcome's occurrence. She is responsible insofar as she changes the respondent's disposition to choose one course of action rather than another. One can assume that provocation does not affect a respondent's choice disposition as much as serious threats would. As Richard Holton and Stephen Shute argue, provocation compromises, rather than eradicates, the respondent's agency. They elaborate that provocation is clearly distinct from an agent's losing control over her body or failing to know what she is doing. There is no (near) complete loss of agency. The agent fails to act upon her reflective judgements or according to her higher-order desires, but this is not to say that she no longer acts intentionally at all. ${ }^{42}$ This suggests that the influence of provocation on the respondent's choice disposition might be more similar to a minor threat, leaving the respondent with a high degree of responsibility if she reacts violently. The model does not suggest that the provocateur will always bear much less responsibility for the wrongful threat than the respondent. It could indeed be the case that the provocateur bears substantial responsibility for the respondent's changed disposition to use force. But it does rule out the possibility of the provocateur bearing full responsibility for the outcome

\footnotetext{
40 Vallentyne, p. 71.

41 Note that Vallentyne attributes the shift to brute luck: "the proposed model views the shift in disposition to choose as a result of a coercive threat as a matter of brute luck." Vallentyne, p. 71. It would be more plausible to attribute the shift to the threatener's responsibility as I suggest in my discussion of the case.

42 Richard Holton, and Stephen Shute, "Self-Control in the Modern Provocation Defence," Oxford Journal of Legal Studies 27(1)( 2007): pp. 51-52.
} 
because this would deny that the respondent is still an agent and in a position to make choices.

So far, we have only been considering the provocateur's and the respondent's agential responsibility and not yet their moral responsibility. Clearly, a victim threatened with serious harm bears no moral responsibility for the loss of her wallet even though the choices she made affected the outcome. But, in the case of provocation, we assumed that the provocateur unjustifiably and culpably provokes. Given the provocateur's full culpability, no proportionality discount will be made. That is, there won't be any adjustment to the extent of the rights forfeiture as would have been the case if the agent had an excuse.

The above analysis suggests that the provocateur does not forfeit all rights against harm and will retain the right to defend against the remainder wrongful harm threatened by the respondent. This will be so even if the provocateur is highly culpable as is the case in the following example of Ferzan.

\section{Funeral}

Imagine a funeral ceremony with hundreds of mourners for a widely respected African-American civil rights leader. A white supremacist appears at the church and begins shouting nonthreatening, racial epithets. Enraged mourners rush the person, who pulls out a concealed gun and kills several of them. ${ }^{43}$

Ferzan and I both consider the use of force against provocateurs wrongful. Ferzan does so on the ground that the provocateur is not liable and has not forfeited rights against harm. My unified forfeiture account explains the impermissibility of the use of force by the fact that it is not instrumental to averting a threat. But our accounts differ with regards to the provocateur's rights against harm and rights to self-defence.

The intuitive wrongness of the provocateur's response is explained by Ferzan's account and is reflected in several jurisdictions that would deny the white supremacist a right to self-defence. Contrary to these accounts, the unified forfeiture account suggests that even in such dramatic cases the provocateur would retain some rights to self-defence against a threat to his life. He would not be allowed to respond with lethal force - not only because he is confronted with a partially excused threat, but also because he forfeited some of his rights against harm. Thus, a lethal response, let alone killing several of the mourners would be disproportionate and impermissible. The provocateur may only use a less harmful means to avert the threat.

The accounts further differ in their assessment of the wrongs done to the provocateur. Ferzan maintains that the provocateur does not forfeit rights against harm for he does not pose a threat. My account is more permissive in this respect. Without condoning the use of force against the provocateur, it suggests that the provocateur is not fully wronged by such harm. The wrong he suffers is less than what an innocent victim would suffer if harmed to the same degree. He contributed to the

${ }^{43}$ Ferzan 2013, p. 598. 
wrongful harm coming about and so forfeited rights against harm in proportion to his wrongful contribution. In this respect, the account might correspond better with our intuitions.

\subsection{Learning from Distributive Justice Accounts of Self-Defence}

Both Ferzan's and my account restrict the defensive rights of a provocateur. As a result, both accounts would deny a provocateur the right to defend with lethal force if the respondent (foreseeably) reacts with lethal force. According to Ferzan, the provocateur forfeits defensive rights against any harm that she foresaw the respondent would inflict. According to the unified forfeiture account, the provocateur forfeits some of her rights because she contributed to a wrongful threat. Some might find even this latter result unappealing, especially if the provocateur bears comparatively less responsibility than the respondent.

Daniel Farrell and Kai Draper build their accounts on the idea of comparative responsibility. Whether a provocateur is permitted to self-defend depends on her responsibility for the threat of harm compared with the responsibility of the respondent. I will briefly outline their accounts and show why reliance on comparative responsibility is insufficiently fine grained to draw clear distinctions between innocent victims and provocateurs. However, I will use some of their insights to improve my own account.

Farrell defends an account of self-defence based on distributive justice. He suggests that "when someone knowingly brings it about, through his own wrongful conduct, that someone else must choose either to harm or to be harmed herself, justice allows the latter to choose that the former shall be harmed rather than that she shall be harmed." 44 Indivisible harm should fall on the person who bears the greater responsibility for the fact that harm has to be distributed. Draper similarly writes "justice typically permits harming the aggressor in defence of his potential victim only if the aggressor is, in the relevant sense, more responsible than his potential victim for the relevant threat." 45 While Farrell suggests that the respondent always bears more responsibility, for it is the respondent "who, in the final analysis, has wrongfully made it the case that someone must suffer," 46 Draper assigns shares in responsibility depending on the specifics of the case. The shares of responsibility in provocation cases depend on the "severity of the provocation relative to the seriousness of the threat." 47 Typically, when severe provocation is met with minor force, the provocateur will be more responsible for the threat and so may not self-defend against the respondent's threat of harm. One further difference of the two accounts is that Farrell relies solely on distributive justice, whereas Draper invokes justice

\footnotetext{
44 Daniel Farrell, "What Should We Say about Contrived 'Self-Defense' Defenses?," Criminal Law and Philosophy 7(3) (2013): p. 573.

45 Kai Draper, War and Individual Rights. The Foundations of Just War Theory (Oxford: Oxford University Press, 2015), p. 78.

46 Farrell, p. 581.

47 Draper, p. 78.
} 
in order to determine who has a right against harm. On his specificationist view of rights, an agent has no right against harm if she poses a threat and is more responsible for this threat than the other involved party. ${ }^{48}$

To see the implications of these claims, think again of our initial provocation case. Upon provocation, the respondent is threatening to harm the provocateur, and our question is whether the provocateur has a right against such harm and/or a right to self-defend. As with all provocation cases, Farrell would suggest that the respondent bears the main responsibility for the threat's coming about since she makes it the case that somebody will suffer harm. Therefore, the provocateur may defend against the respondent's threat. Draper's analysis would take into account the severity of the provocation and of the threat. Depending on the specifics of the case, either the provocateur or the respondent will bear more responsibility and will correspondingly lack rights against harm.

No more fine-grained analysis of the provocation cases is possible with accounts that rely so heavily on the distribution of responsibility as Draper's and Farrell's. This has two undesirable consequences for cases involving only provocateur and respondent. First, if the provocateur has less responsibility, she will not be notably different from innocent victims in terms of what it is permissible for her to do or what rights she has. Second, the accounts shift all the costs to the party who bears more responsibility even though Draper and Farrell admit that these are cases of shared responsibility.

Contrary to what Farrell claims, it is doubtful that an account based on comparative responsibility can distinguish innocent victims from provocateurs in two-person cases. He suggests that provocateurs should be held to a much higher standard than innocent victims in connection with what they may and may not do in self-defence. ${ }^{49}$ By this, Farrell means a "strict honoring of the proportionality requirement" and no willingness to "cut [the provocateur] any moral slack" as one might do when judging the proportionality of an innocent victim's defence. ${ }^{50}$ The provocateur must "be very careful indeed not to do more to [the respondent] than he needs to do in order to prevent her attack and, moreover, to keep the amount of harm he does to [the respondent] strictly within the (admittedly rough) limits of [...] the proportionality limits." 51 But it is unclear how the distributive justice accounts can make sense of these differences in proportionality to explain why an innocent victim may use more force than a provocateur. The strict honouring of the proportionality and minimum harm requirements is demanded of provocateurs and innocent victims alike.

The comparative approaches establish who bears more responsibility for the fact that harm must be distributed. Once it is established who of the parties is permitted or has a right to self-defend, the proportionality of permissible defensive force is determined by the expected harm. As Farrell describes the proportionality constraint, "it requires that the harm inflicted in defending oneself [...] not be radically

\footnotetext{
48 Draper, p. 83.

49 Farrell, p. 582.

50 Ibid.

51 Ibid.
} 
disproportionate to the harms one can reasonably expect to suffer if one does not defend oneself [...]." 52 Since the more responsible party should bear the cost, it is not clear how we can make any more fine-grained distinctions. As long as one party bears less responsibility than the other, whether she is fully innocent or only slightly less responsible, she does not have to bear (any of) the cost. Lazar considers this to be one of the main shortcomings of the distributive justice approach to self-defence. Slight asymmetries in responsibility are, he argues, insufficient to justify the full burden falling on one party rather than the other. ${ }^{53}$

Farrell notes furthermore that provocateurs, unlike innocent victims, can be held morally responsible for paying some (and possibly all) of the costs for repairing the respondent for the harm she incurred. Compensation for harm as a divisible good might more easily reflect shared responsibility. But distributive justice principles usually only require compensation for disadvantages that lie beyond one's responsibility. And since Farrell attributes ultimate responsibility to the respondent because she made it the case that someone must be harmed, it is difficult to see why he could make a claim on the provocateur.

Distributive justice accounts of self-defence fare better in cases involving a third party. Consider Othello again. A third party could save Desdemona only by using the provocateur Iago as a shield against Othello's threat. Here, accounts relying on a comparison of responsibility give a straightforward explanation of why Iago should be harmed to save Desdemona. He bears some responsibility for the threat's coming about, while she bears none.

My account makes the necessary distinctions in both kinds of cases. A provocateur facing a respondent will be allowed to defend against the harm against which she didn't forfeit her rights. Since she shares responsibility with the respondent, her defensive rights are not as extensive as those of an innocent victim. And, in cases such as Othello, it suggests that it is permissible to harm the provocateur because she forfeited some of her rights against harm, and so can become liable to harm if this is instrumental to the aversion of a threat.

Despite these advantages, my account can be improved by insights from distributive justice accounts of defensive harming. These accounts rightly point out that, in self-defence cases, the costs often are indivisible and one of the involved parties will inevitably have to bear the full cost while the other party is spared. Even if in theory it might be possible, as my account suggests, to determine the party's respective shares in responsibility, it will be difficult in practice to share the costs accordingly. My account suggests that Iago and Othello each contributed to the wrongful harm and so each forfeit some of their rights. What if Desdemona can only be saved from death by killing one of them? An indivisible harm must be distributed but, on my account, neither forfeited their rights against lethal harm, only against some less than lethal harm. At this stage, comparative judgements enter my account as well, with the aim of minimizing wrongful harm. Harming either Othello and Iago would mean inflicting less wrongful harm than would otherwise be suffered

\footnotetext{
52 Farrell, p. 573.

53 Seth Lazar, "Responsibility, Risk, and Killing in Self-Defense," Ethics 119(4) (2009): p. 714.
} 
by innocent Desdemona. Closer inspection would also tell us who of the two has more responsibility and so forfeits more of his rights. If Iago forfeits more of his rights, then he rather than Othello should be killed to save the innocent; similarly, if Othello forfeited more of his rights. In this way, the overall wrongful harm would be minimized, and even though Iago did not forfeit his rights against lethal harm, such harm could be justified as a lesser evil. ${ }^{54}$ We can make similar rulings in cases involving only the provocateur and the respondent. Here too, the aim should be to minimize the wrongful harm. The provocateur may therefore only self-defend if this minimizes the overall wrongful harm. This will be the case if she would suffer more wrongful harm at the hands of the respondent than her self-defence would inflict on the respondent.

Comparative judgements thus enter my account at a later stage, and my account thereby takes on some of the insights of distributive justice accounts of self-defence. But my account also recognizes that we must determine the extent to which the provocateur forfeits her rights before moving to the comparative stage. This provides for a more fine-grained analysis of the cases. Having forfeited some of her rights, the provocateur can be distinguished from an innocent victim when facing a respondent who bears more responsibility for the threat's coming about. And, even though the full cost might be indivisible in some cases, and even though it might be permissible to impose that cost on one or the other, my account recognizes that some of the harm wrongs the agent. Knowing the extent of the wrong suffered by the agent will be relevant, inter alia, to the assessment of possible compensation claims.

\section{Conclusion}

In this paper, I considered whether provocateurs retain defensive rights if their provocation leads to violent responses. Previous philosophical work on provocateurs' defensive rights and the legal treatment of provocation cases provide a range of different answers. The actio libera in causa principle applies in many jurisdictions and Ferzan's defence of its alignment with morality suggests that provocateurs forfeit their defensive rights because they themselves bring about the conditions in which they are exposed to harm.

I argued that Ferzan's account is problematic because it explains a provocateur's rights forfeiture by the fact that she created a risk of harm to herself. As I have shown, such a rationale does not have a robust constraint on the extent of rights forfeiture, clashes with intuitions about proportionality, and can make provocateurs worse off than aggressors in terms of defensive rights.

Since these problems stem from the two different rationales that Ferzan invokes for a provocateur's and an aggressor's rights forfeiture, I suggested that a unified forfeiture account, which applies the same rationale across a range of cases, is

\footnotetext{
54 Saba Bazargan similarly justifies the permissibility of killing those who forfeited rights short of the right to life as a lesser evil. See Saba Bazargan, "Killing Minimally Responsible Threats," Ethics 125(1) (2014): pp. 114-136.
} 
preferable. Forfeiture is grounded in moral responsibility for an unjust threat. A provocateur contributes to the creation of a partially excused unjust threat and therefore forfeits some of her defensive rights. She is still not liable to suffer harm because such harm would not be instrumental to the aversion of a threat. The provocateur and the respondent share responsibility for the threat, but how those shares are distributed might vary. However, I argued that the provocateur will not forfeit all her rights against harm and will still be allowed to self-defend with reduced force.

I then contrasted my account with other accounts that rely on judgements of comparative responsibility for the threat coming about. Although my account provides a more fine-grained picture it can be improved by taking on some insights from the accounts relying on comparative responsibility.

Ultimately, I hope to have shown that my account can provide better explanations of intuitively plausible judgements. It brings out the difference between innocent victims and provocateurs and has the further advantage of aligning with the dominant forfeiture accounts of self-defence.

Acknowledgements I would like to thank Krister Bykvist, Johann Frick, Blake Hereth, Mats Ingelström, Daniel Ramöller and an anonymous reviewer for helpful comments on drafts of the paper. I am extremely grateful to Helen Frowe for extensive feedback on several versions of the draft.

Open Access This article is distributed under the terms of the Creative Commons Attribution 4.0 International License (http://creativecommons.org/licenses/by/4.0/), which permits unrestricted use, distribution, and reproduction in any medium, provided you give appropriate credit to the original author(s) and the source, provide a link to the Creative Commons license, and indicate if changes were made.

\section{References}

Alexander, L., and Ferzan, K.K. (2012). “"Moore or Less' Causation and Responsibility.” Criminal Law and Philosophy 6(1), 81-92.

Anderson, E.S. (1999). "What is the Point of Equality?" Ethics 109(2), 287-337.

Bazargan, S. (2014). "Killing Minimally Responsible Threats.” Ethics 125(1), 114-136.

Beebee, H., Mumford, S., Dowe, P., and Moore, M.S. (2013). "Legal Responsibility and Scalar Causation." Jurisprudence 4(1), 102-108.

Bernstein, S. (2017). "Causal Proportions and Moral Responsibility," in David Shoemaker (ed.), Oxford Studies in Agency and Responsibility, Volume 4, Oxford: Oxford University Press.

Draper, K. (2015). War and Individual Rights. The Foundations of Just War Theory. Oxford: Oxford University Press.

Dressler, J. (2008). "Reforming Complicity Law: Trivial Assistance as a Lesser Offense." Ohio State Journal of Criminal Law 5, 427-448.

Fabre, C. (2009). “Guns, Food, and Liability to Attack in War.” Ethics 120(1), 36-63.

Farrell, D. (2013). "What Should We Say about Contrived 'Self-Defense' Defenses?" Criminal Law and Philosophy 7(3), 571-585.

Ferzan, K.K. (2012). "Culpable Aggression: The Basis for Moral Liability to Defensive Killing." Ohio State Journal of Criminal Law 9(2), 669-697.

Ferzan, K.K. (2013). "Provocateurs.” Criminal Law and Philosophy 7(3), 597-622.

Frowe, H. (2014). Defensive Killing. Oxford: Oxford University Press.

Goodin, R. (1985). "Negating Positive Desert Claims.” Political Theory 13(4), 575-598.

Holton, R., and Shute, S. (2007). "Self-Control in the Modern Provocation Defence." Oxford Journal of Legal Studies 27(1), 49-73.

Horder, J. (1992). Provocation and Responsibility. Oxford: Clarendon Press. 
Kaiserman, A. (2017). "Partial Liability." Legal Theory 23(1), 1-26.

Lazar, S. (2009). "Responsibility, Risk, and Killing in Self-Defense." Ethics 119(4), 699-728.

Lazar, S. (2015). Sparing Civilians. Oxford: Oxford University Press.

McMahan, J. (2009). Killing in War. Oxford: Oxford University Press.

Quong, J. (2015). "Proportionality, Liability and Defensive Harm." Philosophy \& Public Affairs 43(2), $144-173$.

Raz, J. (1986). The Morality of Freedom. Oxford: Oxford University Press.

Simons, K.W. (1987). "Assumption of Risk and Consent in the Law of Torts: A Theory of Full Preference." Boston University Law Review 67(2), 213-287.

Vallentyne, P. (2008). "Brute Luck and Responsibility." Politics, Philosophy \& Economics 7(1), 57-80.

Vogt, K. (2007). "The Harshness Objection: Is Luck Egalitarianism Too Harsh on the Victims of Option Luck?" Ethical Theory and Moral Practice 10(4), 389-407. 